\title{
AN ANALYSIS OF THE CHARACTERIZATION OF THE CHARACTERS IN SHORT MOVIE ENTITLED IBU
}

\author{
Dita Aulia Rahmah ${ }^{1}$ \\ ditaaulia97@gmail.com \\ Mutmainah Mustofa ${ }^{2}$ \\ inamustofa@unisma.ac.id \\ Izzatin Nisa ${ }^{3}$ \\ Izzatinnisa5@gmail.com \\ English Education Department \\ University of Islam Malang
}

\begin{abstract}
This research is aimed to know the characterization of the characters and to know the moral values that can we get. The researcher done this research based on analyzing the characteristics of the characters in short movie entitled IBU. The research problems of this research are 1). How is the characterization of the characters? 2). What moral value that we got from the movie?.This research used qualitative descriptive to analyze and interpret the research object in the short movie entitled IBU. The researchers used table analysis in collecting the data. After that, the researchers explain and describe the result based on the table and made a conclusion. Based on the result, the researcher found the characterization of the characters. It is found that Gerry was an antagonist character while the mother was a protagonist character.
\end{abstract}

Keywords: analysis, characters, characteristics, characterization, short movie

\section{INTRODUCTION}

Character is someone who appears in a story, such as in short stories, novels, dramas, or movies.Abrams (1981) revealed that the people who appear in narrative or drama where the readers interpret is having certain moral qualities and inclinations whichdelivered in a speech andactionthat we called it as 'character'. Characters are also known as 'the actor' of the story. The characters that appear in the story have different characteristics. It's supported by Nurgiyantoro (2010) that there are some characteristics that the characters have, namely protagonist and antagonist. A protagonist is that a character who has a good personality that always appears in the whole story. While antagonist is a character who hasa bad personality and it usually contradicts with the protagonist. Characterization is literally differentfrom character and characteristic because ithas a wider meaning. Characterization is covered all about who is the characters, how is the characteristic, and how does the illustration of the story tell us.

\section{British, Jurnal Bahasa dan Sastra Inggris}


According to Nurgiyantoro (2010), there are four kinds of characters based on the differentiation of characterization, namely main character $\&$ peripheral character, protagonist \& antagonist character, flat character \& round character, and static character $\&$ developing character. The differentiation of the characters will be explained as follows:

\section{1) Main Character \& Peripheral Character}

Main Character is the character that always appears in the story from the beginning to the end of the story. It because the main character always appears in the story it makes them influencing the development of the plot. Besides that, Peripheral Characters cannot change the plot a lot because they sometimes appear in the story (it can be in the middle or at the end of the story).

\section{2) Protagonist \& Antagonist Character}

Protagonist Character can be called the hero whom the characters could give a sense of sympathy and empathy. It makes us think that the problem that he/she faced is also a problem that we have. While Antagonist Character is a character that contradicts with the protagonist. This character can cause conflict and tension created between protagonists and antagonists.

\section{3) Flat Character \& Round Character}

A flat character is a character that has one quality of character and action or behavior that reflects their characteristic. While Round Characteris a complex character that has other sides of their personality. It means that the character has many personalities or sometimes cannot predict it.

\section{4) Static Character \& Developing Character}

Static Character is characters who essentially do no change or even developing their characteristic. It means there is no personality change from the beginning to the end of the story. While Developing Character is the contradiction of the static character, where the character has changed and developing their personalities.

On the other hand, moral or called as moral values which contained in the message of a story can be defined as one's personality or an action that we did which can be good or bad. This good or bad action is based on whether we have a

\section{British, Jurnal Bahasa dan Sastra Inggris}


high moral or not. People who have a higher moral can define good or bad things. A moral is about a value that can be bad or good which has been received in action, personality, obligation, manners, and morality. In literary works, moral usually reflects the view of life of the author concerned about the values of truth and what the author wants to convey to the audience (Nurgiyantoro, 2010). It is usually intended as a suggestion related to certain moral teachings that are practical in nature and can be taken or interpreted through the story (Kenny, 1996). Thus, moral is an action or personality in human social life which involving those the right and wrong of the human characters.

The concept of value is still general. It's referred to justice, truth, respect, and honesty. Values are regarded as the reflecting abstract of hidden aspects such as justice, truth, respect, and honesty (Ariyanti, 2016). That statement was supported by Zahroni (2016) who revealed that value is seen to be more basic of the attitude, human behaviors, the type of belief about how to behave which tells us about something right and wrong. To sum up, moral value is a human attitude or behavior which involving the way how they behave that can be right or wrong based on the societies' judgment.

In this research, the researcher would like to analyze the characterization of the characters and the moral value that we can get from the short movie entitled $I B U$. The purpose of this research is to know the characterization of the characters and to know the moral value that can be taken from the short movie. This research usedqualitative research, where the researcher described the characteristics of the characters by the analysis table which consists of two tables namely, the characteristics of the characters and the differentiation of characterization table.

\section{RESEARCH METHOD}

Qualitative research was used in this research. This research was categorized as qualitative research because the researcher analyzed and described the characterization of the characters by using analysis tables. According toDenzin \& Lincoln cited in Moleong (2013) qualitative is research that used a natural setting with intending to interpret the phenomena which occurred and carried out by involving various existing method. Sugiyono (2013) added that qualitative

\section{British, Jurnal Bahasa dan Sastra Inggris}


research is often called naturalistic research because it carried out in a natural setting, it is also known as the ethnographic method because mostly used in the field of cultural anthropology, it is called qualitative research because the data and the analysis were collected qualitatively in nature.

The method that used in this research was the descriptive analysis method. Descriptive analysis is a method whichdone by describing the facts and followed by the analysis (Ratna, 2011). Sugiyono (2009) found that it is a method that serves to describe and give a description of the object under the study through data or samples that have been collected without conducting analysis and making a conclusion that applied to the public. By conductinga descriptive analysis method, the researcher was described the characterization of the characters by the analysis tables. The table of analysis consists of two tables namely, the characteristics of the characters and the differentiation of the characterization table. For the first table consist of the name of characters/actors, characteristic, evidence, and minutes of the scene. While the second tableconsists of the name of characters/actors, differentiation of the characterization, and evidence. There were some steps in collecting the data, which explained as follows:

1. The researcher collected the data by watching the short movie, then made a list of characters, found the action which showed the characteristics of the characters, found the evidence based on the scene of the short movie, and found the minutes of the scene.

2. After collecting the data, the researcher made the analysis tables namely, the characteristic of the characters and the differentiation of the characterization table. Then, the researcher made the descriptions of the characters' characteristics and found the moral values that can be taken from the story.

3. For the last step, the researcher made a conclusion based on the results of the findings.

\section{RESEARCH FINDING AND DISCUSSION}

The data will be displayed in the form of a data analysis table which consists of two tables. The first table has shown the characteristics of the character

\section{British, Jurnal Bahasa dan Sastra Inggris}


and the second table shown the characterization of the characters. The analysis tables were shown as follows.

Table 1 The characteristics of the Characters

\begin{tabular}{|c|c|c|c|c|}
\hline No & $\begin{array}{c}\text { Characters / } \\
\text { Actors }\end{array}$ & Characteristics & Evidence & Minutes \\
\hline 1. & Gerry & $\begin{array}{l}\text { Less of attention, } \\
\text { Less of happiness, } \\
\text { Misunderstanding, } \\
\text { Do not care, } \\
\text { Could not appreciate the } \\
\text { effort of his parent, } \\
\text { Vengeful, } \\
\text { Disobedient, } \\
\text { Regretful }\end{array}$ & 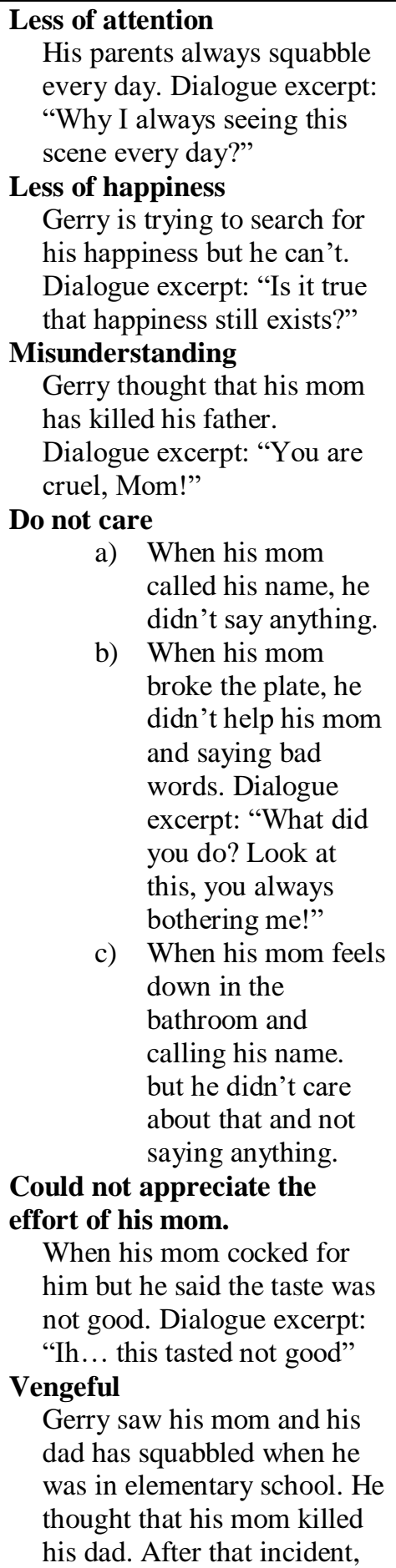 & $\begin{array}{l}01: 40 \mathrm{sec} \\
04: 37 \mathrm{sec}\end{array}$ \\
\hline
\end{tabular}

\section{British, Jurnal Bahasa dan Sastra Inggris}




\begin{tabular}{|c|c|c|c|c|}
\hline & & & $\begin{array}{l}\text { he never forgets it until now. } \\
\text { Dialogue excerpt: "Those } \\
\text { memories still on my hearts". } \\
\text { Disobedient } \\
\text { It happened when his mom } \\
\text { was sleeping, while the } \\
\text { house had been robbed. } \\
\text { Gerry was very angry and } \\
\text { said to take his mom to the } \\
\text { nursing house. Dialogue } \\
\text { excerpt: "You are useless! I } \\
\text { can't take it anymore. You } \\
\text { must be sent to the nursing } \\
\text { house!" } \\
\text { Regretful } \\
\text { One day, Gerry met the old } \\
\text { neighbor namely Kang } \\
\text { Asep. He explained the } \\
\text { incident that happened } \\
\text { between his mother and } \\
\text { father. He said that it was an } \\
\text { accident, his mom tried to } \\
\text { take custody of him because } \\
\text { his father was a drunker, } \\
\text { gambler, and liked to play a } \\
\text { girl. Then, his father would } \\
\text { like to hit her mom. } \\
\text { Unfortunately, his father had } \\
\text { a heart attacked and died. } \\
\text { After knowing the truth, } \\
\text { Gerry came to the nursing } \\
\text { house and asked for an } \\
\text { apology from his mom. } \\
\text { Dialogue excerpt: "Please } \\
\text { forgive me, Mom ". }\end{array}$ & $\begin{array}{l}07: 54- \\
10: 01 \mathrm{sec}\end{array}$ \\
\hline 2. & Mother & $\begin{array}{l}\text { Full of love \& Kindness, } \\
\text { Hard-worker, } \\
\text { Independent, } \\
\text { Forgiveness }\end{array}$ & $\begin{array}{l}\text { Full of love \& Kindness } \\
\text { a) Although her son hates } \\
\text { her and didn't care } \\
\text { about her, she always } \\
\text { keeps smiles and gives } \\
\text { her attention to him. } \\
\text { b) When his son blamed } \\
\text { her because the house } \\
\text { had been robbed, after } \\
\text { that his son sent her to } \\
\text { the nursing house. She } \\
\text { never cursed him or } \\
\text { saying bad words. } \\
\text { Hard-worker } \\
\text { She never gives up on her } \\
\text { son. Besides that, she always } \\
\text { works hard to earn money as } \\
\text { a tailor. } \\
\text { Independent }\end{array}$ & $\begin{array}{l}01: 36 \mathrm{sec} \\
\\
05: 47- \\
06: 14 \mathrm{sec}\end{array}$ \\
\hline
\end{tabular}

\section{British, Jurnal Bahasa dan Sastra Inggris}




\begin{tabular}{|c|c|c|c|c|c|}
\hline & & & \multicolumn{2}{|c|}{$\begin{array}{l}\text { After her husband was } \\
\text { passed away, she can live } \\
\text { alone with her son without } \\
\text { any help from other people. } \\
\text { Forgiveness } \\
\text { She forgives her son when } \\
\text { her son came to the nursing } \\
\text { house for asking forgiveness } \\
\text { to her. }\end{array}$} & 更 \\
\hline 3. & Father & $\begin{array}{l}\text { Grumpy, } \\
\text { Drinker, Gambler, \& } \\
\text { Player (playing with a } \\
\text { girl) }\end{array}$ & \multicolumn{2}{|c|}{$\begin{array}{l}\text { Grumpy } \\
\text { a) When he squabbled with } \\
\text { his wife, he wanted to hit } \\
\text { her. } \\
\text { b) He cannot keep his } \\
\text { temper until he got heart } \\
\text { attacked. } \\
\text { Drinker, Gambler \& Player } \\
\text { (playing with a girl) } \\
\text { When squabbled with his } \\
\text { wife, his wife said that her } \\
\text { husband was a drinker, } \\
\text { gambler, and a player } \\
\text { (playing with a girl). }\end{array}$} & $\begin{array}{l}08: 27 \mathrm{sec} \\
08-30 \mathrm{sec}\end{array}$ \\
\hline 4. & Gerry's Wife & $\begin{array}{l}\text { Kind, } \\
\text { Frightful }\end{array}$ & b) & $\begin{array}{l}\text { When she would like } \\
\text { to get married to Gerry, } \\
\text { she said to him to meet } \\
\text { with his mother for } \\
\text { asking for a blessing. } \\
\text { Besides that, Gerry } \\
\text { looks like doesn't want } \\
\text { it. Then, she said that } \\
\text { Gerry must respect his } \\
\text { mother. Dialogue } \\
\text { excerpt: "We should } \\
\text { meet your mother first. } \\
\text { You must be respectful } \\
\text { to your mother!". } \\
\text { After she got married } \\
\text { to Gerry, she said to } \\
\text { him to take his mom to } \\
\text { live together with } \\
\text { them. Dialogue } \\
\text { excerpt: "we have to } \\
\text { invite your mother to } \\
\text { live with us!" } \\
\text { She helped her mother- } \\
\text { in-law when she broke } \\
\text { the plate. } \\
\text { She always stood up } \\
\text { for her mother-in-law } \\
\text { when her husband } \\
\text { would like to send her } \\
\text { mother to the nursing } \\
\text { house, she tried to }\end{array}$ & $\begin{array}{l}05: 00 \mathrm{sec} \\
06: 12- \\
06: 16 \mathrm{sec}\end{array}$ \\
\hline
\end{tabular}

\section{British, Jurnal Bahasa dan Sastra Inggris}




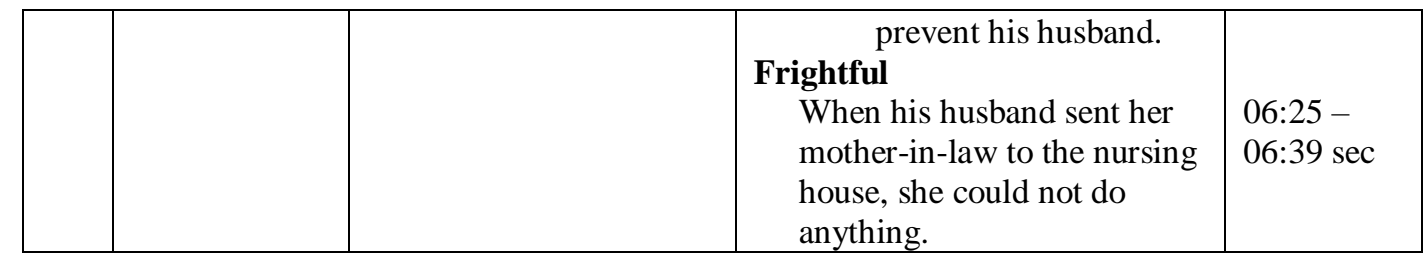

Table 2 The differentiation of the characters

\begin{tabular}{|c|c|c|c|}
\hline No & $\begin{array}{c}\text { Characters / } \\
\text { Actors }\end{array}$ & $\begin{array}{l}\text { Coded } \\
\text { Data }\end{array}$ & Evidence \\
\hline 1. & Gerry & $\mathrm{MC}, \mathrm{AC}, \& \mathrm{DC}$ & $\begin{array}{l}\text { MC: } \\
\text { He always appears from the beginning to the end } \\
\text { of the movie. } \\
\text { AC: } \\
\text { He always saying bad words to his mom and sent } \\
\text { his mom to the nursing house. Dialogue excerpt: } \\
\text { a) You are cruel, mom! } \\
\text { b) What did you do? Look at this, you } \\
\text { c) "You are useless! I can't take it anymore. } \\
\text { DC: You must be sent to the nursing house!" } \\
\text { The first time Gerry hates her mom but at the } \\
\text { end of the story, he asked for an apology from } \\
\text { his mom. After that, he treats his mom nicely. } \\
\text { Dialogue excerpt: "Please forgive me, Mom ". }\end{array}$ \\
\hline 2. & Mother & $\begin{array}{l}\text { MC, ProC, \& } \\
\text { SC }\end{array}$ & $\begin{array}{l}\text { MC: } \\
\text { She always appears from the beginning to the } \\
\text { end of the movie. } \\
\text { ProC: } \\
\text { She never hates his son although his son treats } \\
\text { her badly. She also forgives her son at the end of } \\
\text { the movie. } \\
\text { SC: } \\
\text { From the beginning until the end of the movie } \\
\text { the character of the "Mother" does not change. }\end{array}$ \\
\hline 3. & Father & $\mathrm{PC}$ & $\begin{array}{l}\text { PC: } \\
\text { Only appear in a glance of the movie. }\end{array}$ \\
\hline 4. & Gerry's Wife & $\mathrm{PC}$ & $\begin{array}{l}\text { PC: } \\
\text { Only appear in a glance of the movie. }\end{array}$ \\
\hline 5. & Kang Asep & $\mathrm{PC}$ & $\begin{array}{l}\text { PC: } \\
\text { Only appear in a glance of the movie. }\end{array}$ \\
\hline
\end{tabular}

\section{Coded data descriptions:}
1. MC : Main Character
2. PC : Peripheral Character
3. ProC : Protagonist Character
4. AC : Antagonist Character
5. FC : Flat Character

\section{British, Jurnal Bahasa dan Sastra Inggris}




\section{RC : Round Character \\ 7. SC : Simple Character \\ 8. DC : Developing Character}

Based onthe table 1, it was shown the characteristics of the characters/actors. While in table 2, it was shown the characterization of the characters. As we can see from the analysis tables above, we can conclude that the actors can be categorizedbased on the 'differentiation of the characterization' stated by Nurgiyantoro (2010). It will be explained as follows.

\section{Main Characters}

Based on table 2, there are two main characters which are Gerry and the mother. It is called the main character because both Gerry and mother always appearin the whole of the story.

\section{Peripheral Characters}

There are four peripheral characters which are father, Gerry's Wife, and Kang Asep. They were called peripheral characters because they only appear in a glance and it didn't change the story.

3. Antagonist Characters

Gerry was categorized as an antagonist character because he had bad personalities. From the movie, we can see that he was disobedient and always saying bad words to his mom until he sent his mom to the nursing house (See table 1).

4. Protagonist Characters

The mother was categorized as a protagonist character because although her son treated her badly, she never cursed him. As we can see at the end of the movie, when her son came to the nursing house and asking for an apology, she still forgives her son (see table 1).

5. Simple Characters

Based on the movie, the mother has a simple character whose characteristics never change from the beginning until the end of the story. Gerry's mother was a very kind person even her son treated her bad, she

\section{British, Jurnal Bahasa dan Sastra Inggris}


never hated or even cursed him. At the end of the movie, she also forgives her son (see table 1). It can prove that the mother has a simple character.

6. Developing Characters

Gerry has a developing character because from the beginning of the movie he treated his mom badly but at the end he asking for an apology from his mom and treats her nicely. It happens when he saw his parents squabbled and thought that his mom killed his father. After that incident, he hates his mom and treated her badly. After knowing the truth, he asking for an apology and treat his mom nicely (see table 1).

Based on the short movie entitled $I B U$, some moral values can be taken as follows.

1. It would be better for us to listen to the truth first before making a conclusion that makes us misunderstand.

2. Never say bad words to our parents. If we hurt their heart, we will never get the blessing of our parents and our life might be miserable.

3. Never treat your parents badly or you will regret it.

4. Do not forget about the struggle of our parents especially your mother who raise you.

\section{CONCLUSION}

Based on the finding \& discussion, the researcher found the characterization of the main characters. In the short movie entitled $I B U$, the author shows the characterization of the main characters which are Gerry as an antagonist character and the mother as a protagonist character. Not only that, but the author also shows there is a changing character at the end of the movie and it happen on Gerry's characteristics. In this case, Gerry is not only an antagonist character but he also sustains to be a developing character. While the mother is not only protagonists character but she also a simple character. Here, the characteristics of the mother do not change.

\section{British, Jurnal Bahasa dan Sastra Inggris}




\section{REFERENCES}

Abrams, M.H. 1981. A Glossary of Literary Terms. New York:Holt, Rinehart and Winston.

Ariyanti. 2016. Moral Values in Education: Teaching English Classroom at Ma'had Tahfizul Qur'an Rahmatullah Samarinda. Script Journal, Vol. 1 Issue. 1:11-24, http://jurnal.fkip-uwgm.ac.id/index.php/Script

Kenny, W. 1966. How to Analyze Fiction. New York: Monarch Press.

Moleong, L.J. 2013. Metodologi Penelitian Kualitatif. Bandung: PT. Remaja Rosdakarya.

Nurgiyantoro, B. 2010. Teori Pengkajian Fiksi. Bulaksumur, Yogyakarta: Gajah Mada University Press.

Ratna, N.K. 2011. Teori, Metode, dan Teknik: Penelitian Sastra. Yogyakarta: Pustaka Pelajar.

Sugiyono. 2009. Metode Penelitian Kulitatif dan R\&D. Bandung: Alfabeta.

Sugiyono. 2013. Metode Penelitian Kulitatif dan R\&D. Bandung: Alfabeta.

Zahroni. 2016. An Analysis of Characters in "I Love You Mom" Short Story Book by Arleen Admijaja. Literacy Criticism Journal. Vol. 3 No. 1:40-52, https://jurnal.unived.ac.id 